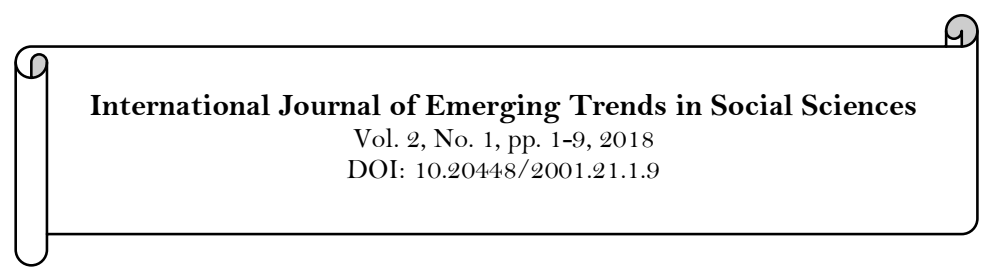

\title{
The Questions Technique in Guided Paragraph Writing
}

\author{
Ameerchund Maharaj ${ }^{1}$ \\ Turki Alsolami ${ }^{2}$ \\ 1,2King Abdul Aziz University, Jeddah, Saudi Arabia. \\ Email:ashrafmaharaj@yahoo.com \\ Email:tgalsolami@,kau.edu.sa
}

\begin{tabular}{|c|c|}
\hline Abstract & \\
\hline $\begin{array}{l}\text { Writing has always been an onerous task for ESL learners, especially } \\
\text { those in the beginner - and elementary phases of English language } \\
\text { acquisition. Teaching ESL writing has always been viewed and } \\
\text { implemented using the L1 framework. This may account for the } \\
\text { frustrations experienced by both teacher and students in ESL classes. } \\
\text { New techniques and strategies have to be devised taking into } \\
\text { account the unique circumstances of ESL learners. Using an } \\
\text { experimental design, this study compared the number of writing } \\
\text { errors made in a control and experimental group. The control group } \\
\text { was taught paragraph writing in the conventional way incorporating } \\
\text { elements of the product and process approaches to writing. The } \\
\text { experimental group was given a pre-arranged set of questions to } \\
\text { which they had to respond in a specific manner. It was found that the } \\
\text { number of errors committed by the experimental group were } \\
\text { significantly lower than the control group, thus suggesting that the } \\
\text { Questions technique does have merit in teaching writing to ESL } \\
\text { learners. It is versatile in the sense that it can be adapted for different } \\
\text { ability levels and types of paragraphs. }\end{array}$ & $\begin{array}{l}\text { Keywords: } \\
\text { Questions technique } \\
\text { Writing errors } \\
\text { Writing skills } \\
\text { Guided paragraph writing. }\end{array}$ \\
\hline
\end{tabular}

\section{Introduction}

Of all the skills in English language learning, writing is probably the most challenging for learners to master, and teachers to teach. In the case of Reading, Speaking and Listening, the reasons for engagement are more or less immediately self-evident, the process itself moves fairly quickly from beginning to end, errors are quickly identified and corrected and not all errors are singled out for attention, remediation, or correction. There are many factors involved in Writing. While Listening, Speaking and Reading occur instantaneously, and sometimes if not often, spontaneously, Formal Writing is a more calculated, deliberate act. It doesn't occur instantly and is then over! The mere physical act of picking up a pen/pencil or clicking a mouse to open "Microsoft Word" to begin typing signifies that the person's brain has already started thinking what he/she is going to write. In her examination of second language writing Sokolik (2003) explains that writing is a mental process of generating ideas and deciding how best to present these ideas in the form of a written text. Writers, she says, "typically serve two masters: themselves, and their own desires to express an idea or feeling, and readers, also called the audience, who need to have ideas expressed in certain ways" (Sokolik, 2003). Learners, especially the novice, often approach the Writing task with some trepidation, not least of all because he/she is being asked to produce or create a written text, be it a sentence, short paragraph, e-mail report, memo or letter. The anxiety is also due in part to the fact that others, that is, teachers and peers, will be privy to the text that has been produced. It is more often than not going to be read by significant others.

\section{Reason for the Study}

As mentioned previously, writing is a big challenge or hurdle for ESL/EFL learners. At the turn of the millennium, Myles (2002) said: "L1 models of writing instruction and research on composing processes have been the theoretical basis for using the process approach in L2 writing pedagogy". This is a serious critique of the didactics of writing in ESL/ESL classes. The implication of this statement is that as long as teachers are going to use the L1 framework or prototype, students are going to struggle with their writing tasks. Researchers and linguists have constantly made reference to the concept of "interference" where the learners 
L1 hampers skill building in the target language. In the case of the authors' present situation where students L1 is Arabic, the interference can clearly be seen in the following example:

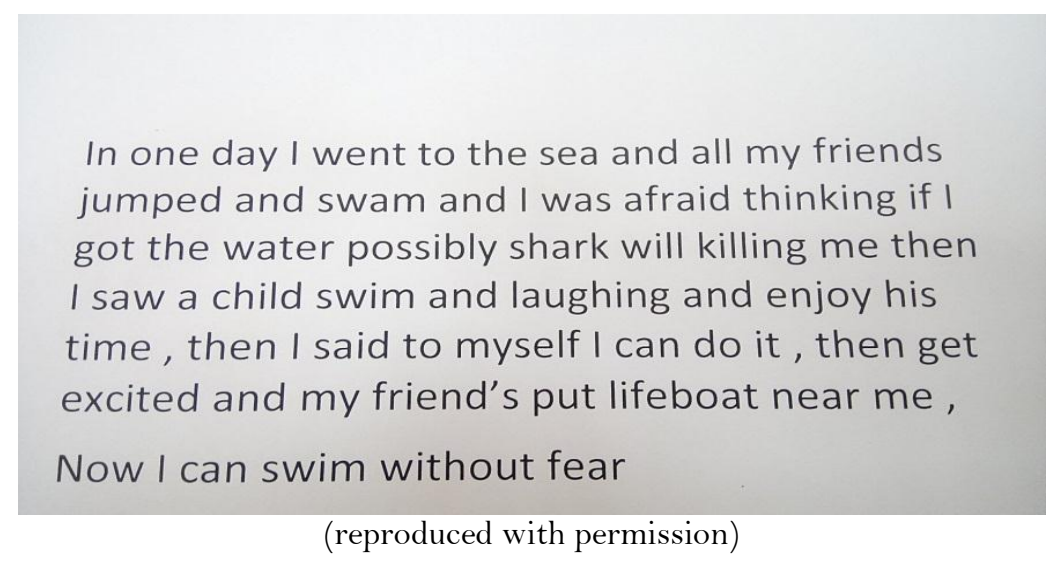

In the above text, the student has attempted to write an English paragraph with an Arabic "mentality". The syntactical and sentence construction errors coupled with a lack of punctuation conventions could be attributed to the absence of the capital letters (higher case) in Arabic. The idea that one sentence completes/expresses a thought has eluded the student, possibly because of a constant shift in his mental processes between Arabic and English. He may be thinking content wise in English but structurally in Arabic. Thus the "run-on" nature of the paragraph.

In the second example the interference is much clearer.

"The special dish of saudi Arabia is kabsa it is made of rice and meat it is eaten eid ul fatter, the food is usually prepare chef, we buy all the ingredients from supermarket, we serve the kabsa on a big plate and about 5 or 6 people eat from same plate"

\section{(reproduced with permission)}

Even though this paragraph was written on the board by the teacher as a model text, the student in this transcription only observed 2 (out of 8 ) instances of capitalization! Interference could also mean that the learners' culture, cognitive linguistic ability, the quality of teaching, etc. could all have a detrimental effect on the student's writing in the target language. From the above discussion and examples, it becomes clear that the L1 model may not be the best strategy to facilitate writing skills in EFL/ESL learners. New strategies have to be embarked on. Before expanding on the new Questions technique developed by the authors, it may be necessary to provide a literature overview of the approach to writing in EFL/ESL.

\section{Literature Review}

Recent years have seen a growing scholarly interest in the assessment of writing skills (Aryadoust, 2014).

A useful starting point might well be asking the question: "Why do we write?" Nunan (2015) draws a distinction between writing for "real-world" purposes and writing for learning. The former refers to texts that one would typically produce in one's practical day-to-day situations, for example, a shopping list, an email to a friend, a mobile phone text message, etc. While the author suspects that most of this real-world written communication may be in the learner's native (L1) language, the latter will of necessity be in English. Writing for learning will essentially be the ESL/EFL instruction a person receives in the more formal setting of a classroom at a university, school or college. This would cover exercises in sentence and paragraph construction, conversation writing, reports, business letters, writing recipes, compositions, etc. Nunan states that the difference between writing for real-world purposes and writing for learning are not mutually exclusive and that a connection can and should exist between the two. It is quite possible that as the student becomes more proficient in writing for learning he/she may gradually slip into the habit of using English (the target language) for real-world purposes. The former purpose can and should inform the latter, not vice versa.

There are various approaches to writing but the two most common are what researchers term the 'Product versus Process" approaches to writing. As the label suggests the Product approach lays emphasis on the final product of the writing effort. A teacher using this approach would expose his/her learners to model texts (by way of the textbooks, internet, personal writing etc.) that should be emulated in structure and style. Modelling is a central feature of this approach for 2 reasons: firstly, it provides valuable feedback to students, and secondly, it is an effective teaching tool if used judiciously in the writing lesson (Saeidi \& Sahebkheir, 2011). The Product approach lays great stress on grammatical accuracy and technical structure. One of the criticisms levelled against this mode of writing is that it is too mechanical and thus inhibits creativity. 
The Process approach on the other hand advocates a series of successive stages before arriving at the final product. These stages all involve constant thinking and re-thinking, planning, editing, and revising. In the Process approach the students work through multiple drafts and at each stage there is editing be it self - peer , parent -, or teacher editing. A perceived drawback of this approach is that because of the extensive freedom it allows, factual or technical (report) writing can become a problem for learners.

In relation to the Process model, some researchers have recently developed what is known as the "Postprocess" approach to writing. In the Process approach writing is conceived of as a cognitive multi-phased continuum where learning occurs through doing, and the teacher is merely a guide or facilitator. Atkinson (2003) states that the Post-process model includes everything that is subsequent to this period of L2 writing and research.

The salient features of all three approaches to writing may be summed up in the following table:

Table-1. Comparison of the Product, Process, and Post-process approaches to Writing.

\begin{tabular}{|c|c|c|}
\hline Product approach & Process approach & Post-process approach \\
\hline 1. Topics are assigned & $\begin{array}{l}\text { 1. Writing is self-initiated: } \\
\text { everybody has a story to tell }\end{array}$ & $\begin{array}{l}\text { 1. Writing is sometimes self- } \\
\text { initiated and sometimes teacher- } \\
\text { assigned. }\end{array}$ \\
\hline $\begin{array}{l}\text { 2. Expository essays are the staple } \\
\text { of school writing. }\end{array}$ & $\begin{array}{l}\text { 2. All modes of writing are } \\
\text { respected equally. }\end{array}$ & $\begin{array}{l}\text { 2. All modes of writing are } \\
\text { respected equally, but teachers will } \\
\text { intervene to make certain a variety } \\
\text { of genres are undertaken. }\end{array}$ \\
\hline $\begin{array}{l}\text { 3. Grammar study, handbook } \\
\text { rules, and exercises lead to good } \\
\text { writing. }\end{array}$ & $\begin{array}{l}\text { 3. Pre-writing, writing, and re- } \\
\text { writing produce good writing. } \\
\text { Mini lessons and student-teacher } \\
\text { conferences are the basis of good } \\
\text { instruction. }\end{array}$ & $\begin{array}{l}\text { 3. Pre-writing, writing, and re- } \\
\text { writing produce good writing. } \\
\text { Mini lessons and conferences are } \\
\text { still primary, but mini lessons may } \\
\text { be longer and more sequenced. }\end{array}$ \\
\hline $\begin{array}{l}\text { 4. Good writing is based on } \\
\text { models and formal guidelines. }\end{array}$ & $\begin{array}{l}\text { 4. Meaning precedes and } \\
\text { determines questions of form. }\end{array}$ & $\begin{array}{l}\text { 4. Teachers may intervene more } \\
\text { directly than in a process model to } \\
\text { tell writers which forms work and } \\
\text { which do not. }\end{array}$ \\
\hline
\end{tabular}

Source: Milner, Milner, and Mitchell (2012).

From the table it can be concluded that the Post-process model is quite flexible and contingency-based, that is, teacher input occurs as and when necessary. While the Questions technique advanced by the authors embrace elements of the Product (emphasis on correct grammar) and Process approaches (encourages revisions of drafts), it is the flexibility and contingency nature of the Post-process approach that is inherent in the Questions technique. In this sense one could say that the Questions technique is eclectic in nature.

Research into both L1 and L2 writing has shown that students' writing skills expand as their neural connections, linguistic insights, and cognitive functions develop (Abbott, Berninger, \& Fayol, 2010; Berninger et al., 2010). While L1 learners do require cognitive strategies necessary to build coherent paragraphs, they usually have a fair amount of linguistic capability and therefore require little or no assistance with vocabulary (Nation, 2006). On the other hand L2 writers could struggle both with poor cognitive strategies and limited linguistic abilities. To help these learners develop their writing skills, L2 researchers and practitioners have generated and implemented a host of "pedagogical interventions" in L2 instruction (Benevento \& Storch, 2011). One would like to think that the Questions technique developed by the authors is just such an intervention!

ESL students' writing and the writing errors they make are well documented (Al-Khasawneh, 2010; Ghabool, Mariadass, \& Kashef, 2012; Maros, Hua, \& Salehuddin, 2007; Musa, Lie, \& Azman, 2012). In an effort to minimize errors L2 writing instructors should always keep in mind strategy development as well as language skill development when working with students (Myles, 2002). Strategy development can and should lead to language skill development.

The idea of first language interference in L2 writing has been the subject of intense research over the last few decades. This has been briefly alluded to earlier in the reason for the present study. Interferences also occur in other language contexts. For example, a review of the related studies on English language learning in Malaysian schools context shows clearly that the first language (Bahasa Malaysia) interferes to a large extent with the second language learning (Maros et al., 2007).

\section{Methodology}

Two separate investigations were carried out in this study. The approach used in this study was experimental in nature. This involved the use of a control - and experimental group. In the control group students were taught paragraph writing in the more or less traditional way. What is the traditional way? Students were given the topic that they had to write about. There was brainstorming of ideas accompanied by 
mind mapping, diagrammatic sketches, etc to organize thoughts into a coherent framework before the actual writing could start. Students were exposed to new vocabulary and phrases associated with the topic. The learning was emphasized, that is, the mandatory use of a topic sentence, supporting sentences and concluding sentence. In addition, a few model paragraphs were made available to learners so that they had some idea of what their final product should resemble. After writing their first draft, a series of editing sessions ensued with students editing their own efforts and then moving onto editing of their peer's paragraph. Students wrote their final drafts after the editing sessions and submitted them to the teacher for marking and evaluation. One could say that this conventional method adopted for paragraph writing is a sort of mixture of the product versus the process approach in writing.

The students in the experimental group were exposed to a different kind of lesson. They were given a "paragraph" of questions on the topic "My neighborhood" refer to Table 2 below.

My neighborhood

Table-2. A paragraph of questions (My neighborhood).

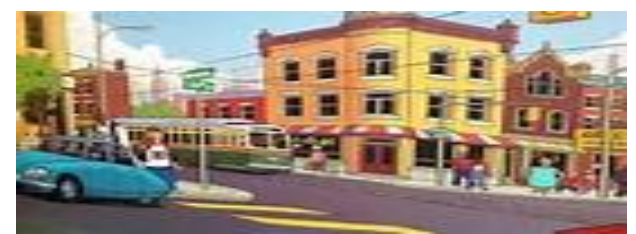

What is your name? In which district do you live? When did you first move to this district? Do you live in a house/apartment? How many bedrooms are there? What can you see from your bedroom window? Is your neighborhood busy or quiet? Which shops are near your house/apartment? What is the biggest problem in your neighborhood? Why do you like/dislike your neighborhood?

After a brief discussion of what a neighborhood is and some pictures as illustration, students were required to respond to each question in the "paragraph of questions" in the following way:

- They had to answer each question by writing ONE full sentence per question.

- Their answers had to follow the same order and format of the questions.

- They had to take special note of new/unfamiliar words, phrases in the questions and if used again in their answers, the spelling of the particular word/phrase had to be correct.

The hypothesis in this study was that there would be fewer errors in the experimental groups. After both lessons with the control - and experimental groups, students' paragraphs were marked using a marking code (refer to Table 3 below).

Table-3. The Marking Code used.

- pun = punctuation

sp = spelling

- $\sin / \mathrm{pl}=$ singular/plural

- art = article

- prep $=$ preposition

- wW = wrong word
- ow = omitted word

- syn = syntax/word order

- pron = pronoun

- inf = infinitive

- iv = incorrect verb/verb tense

The code was carefully recorded on students' scripts depending on the type of error made (see sample of marked script for the control and experimental group in ADDENDUMS 1 AND 2 respectively). The number of errors in each code for each student in both control and experimental groups was then carefully tallied. 


\section{Findings (First Investigation)}

As mentioned previously, the hypothesis for this study was that there would be a significant reduction in the number of writing errors in the experimental groups. A total of 25 scripts for the Control and 25 for the Experimental group were checked and used for analysis. The number of errors in each code for each group is presented below Table 4 .

\begin{tabular}{|c|c|c|c|c|c|c|c|c|c|c|c|}
\hline \multicolumn{7}{|c|}{$\mathrm{CG}=$ Control Group } & \multicolumn{5}{|c|}{$\mathrm{EG}=$ Experimental Group } \\
\hline pun & spell & sing/pl & art & prep & ww & ow & wo/syn & pron & verb & inf & \\
\hline $\begin{array}{l}\mathrm{CG} \\
\mathrm{EG}\end{array}$ & $\begin{array}{l}\mathrm{CG} \\
\mathrm{EG}\end{array}$ & $\begin{array}{l}\mathrm{CG} \\
\mathrm{EG}\end{array}$ & $\begin{array}{l}\mathrm{CG} \\
\mathrm{EG}\end{array}$ & $\begin{array}{l}\mathrm{CG} \\
\mathrm{EG}\end{array}$ & $\begin{array}{l}\mathrm{CG} \\
\mathrm{EG}\end{array}$ & $\begin{array}{l}\mathrm{CG} \\
\mathrm{EG}\end{array}$ & $\begin{array}{l}\text { CG } \\
\mathrm{EG}\end{array}$ & $\begin{array}{l}\mathrm{CG} \\
\mathrm{EG}\end{array}$ & $\begin{array}{l}\mathrm{CG} \\
\mathrm{EG}\end{array}$ & $\begin{array}{l}\mathrm{CG} \\
\mathrm{EG}\end{array}$ & \\
\hline $92 \quad 94$ & $72 \quad 37$ & $\begin{array}{ll}11 & 3\end{array}$ & $25 \quad 19$ & 229 & $\begin{array}{ll}9 & 5\end{array}$ & $26 \quad 21$ & 220 & 7 & 41 & 7 & 3 \\
\hline
\end{tabular}

Discussion of Findings for the First Investigation

A quantitative analysis revealed that there was a significant reduction in the amount of errors across almost all marking codes in the experimental group. With the exception of Punctuation, there was a marked decrease in the number of errors from the control to the experimental group.

In the case of Punctuation, there was a slightly higher number of errors in the experimental group. A possible explanation for this can be found in the idea of first language interference as outlined in the literature review section of this paper. The capital (higher case) letters are not a feature of the Arabic language. Another factor to consider is the lack of concentration. Students may have not realized that in answering one question in a full sentence, one complete thought/idea had been expressed and thus a full stop (period) was required. This resulted in run on sentences with no higher case letters being used.

The number of errors in the Spelling category was almost halved in the experimental group. Students were told that they had to take careful cognizance of words that were in the questions. If they were using the same word/s in their answers, they should have no excuse for wrong spelling!

The most compelling reason for advancing the Questions technique to paragraph writing could be found

in the Word order/Syntax code. There were no errors in syntax in the experimental group. In answering the questions as they appeared on the whiteboard, they were actually modeling the underlying structure of the question. This becomes all the more significant when compared with the preponderance of syntactical errors in the control group (22 in all).

\subsection{Findings (Second Investigation)}

In the second investigation, a total of 14 scripts in both control and experimental groups were checked and analysed. The number of errors in each code in each group is presented below Table 5 .

Table-5. Results of the Second Investigation.

\begin{tabular}{|c|c|c|c|c|c|c|c|c|c|c|}
\hline pun & spell & sing/pl & art & prep & $\mathbf{w w}$ & ow & wo/syn & pron & verb & inf \\
\hline $\begin{array}{l}\mathrm{CG} \\
\mathrm{EG}\end{array}$ & $\begin{array}{l}\mathrm{CG} \\
\mathrm{EG}\end{array}$ & $\begin{array}{l}\mathrm{CG} \\
\mathrm{EG}\end{array}$ & $\begin{array}{l}\mathrm{CG} \\
\mathrm{EG}\end{array}$ & $\begin{array}{l}\mathrm{CG} \\
\mathrm{EG}\end{array}$ & $\begin{array}{l}\mathrm{CG} \\
\mathrm{EG}\end{array}$ & $\begin{array}{l}\mathrm{CG} \\
\mathrm{EG}\end{array}$ & $\begin{array}{l}\mathrm{CG} \\
\mathrm{EG}\end{array}$ & $\begin{array}{l}\mathrm{CG} \\
\mathrm{EG}\end{array}$ & $\begin{array}{l}\mathrm{CG} \\
\mathrm{EG}\end{array}$ & $\begin{array}{l}\mathrm{CG} \\
\mathrm{EG}\end{array}$ \\
\hline $61 \quad 65$ & $24 \quad 12$ & O 2 & $16 \quad 13$ & $11 \quad 12$ & 1 & 99 & $2 \quad 0$ & 1 & $17 \quad 10$ & 3 \\
\hline
\end{tabular}

\subsection{Discussion of Findings for the Second Investigation}

As in the case of the first investigation the number of errors for Punctuation in the experimental group exceeded that of the control group. In addition to the explanations given above, it was noticed that in many cases letter formation is a problem. The student may intend writing a higher case letter but the actual imprint on the paper resembles a lower case, and vice versa. The full stop (period) was also not always clearly delineated or formed. Carelessness or forgetfulness could also be contributing factors. However this can be rectified through constant repetition, short practice drills, and demonstration exercises where punctuation is deliberately omitted and students fill in the correct punctuation marks in the appropriate places.

As in the case of Punctuation, there were other codes in which the control group had fewer errors than the experimental group. However the differences in the number of errors were minimal. The experimental group had significantly reduced number of errors in Spelling and Verb usage. There were also a smaller number of errors in the experimental group for use of the Article and Syntax (word order) but these were negligible. Interestingly enough, there were an equal amount of errors for Control and Experimental groups in the Omitted word and Infinitive categories. An important caveat is that the class for the Second Investigation was a beginner level entry class not very used to writing full sentences let alone paragraphs. Fresh out of high school they, that is, the control group had to be given extra assistance in spelling, sentence construction, elements of grammar, punctuation and vocabulary. This might account for the control group having committed fewer errors than the experimental group in some codes, thus seeming to nullify the hypothesis. 


\section{Limitations of the Study}

The evidence to claim the effectiveness of the Questions technique has been based on two sets of classroom experimentation. As such, it could be tantamount to what Nunan (2003) terms "one-shot research". In order to strengthen reliability and validity of findings, two separate investigations over two semesters were undertaken. However this might not be enough to establish the effectiveness of the Questions technique over other approaches. For a study of this nature to claim more reliability and validity, more comparisons between the Questions technique and more traditional approaches might have to be undertaken.

One of the criticisms that can be levelled at the Questions approach is that it constrains students' written responses. In other words, the questions dictate how students should respond. Responses may tend to become too mechanical, robotic and thus all creativity is lost. While this may be true in the initial stages of the approach when students' levels are very low, the potential for more varied, creative written responses increases as the students' linguistic skills develop. In fact the Questions technique strongly advocates the use of more open - ended questions as students' ability levels and confidence in using the language grow and expand. This actually forms the basis of further research where the whole issue of how creativity can be fostered using the Questions technique is tackled.

Using peer evaluation as part of the Process approach in control groups does become a problem. Because the students' level is so low, they cannot really check and correct their peers' work. They are not in a position to identify mistakes in grammar, spelling, sentence construction, etc. The authors had to work within this constraint.

\section{Conclusion}

The question uppermost in a learner's mind seconds before he/she picks up a pen to write is: "Where do I start?", "What will be my first words?" It's easy to talk about brainstorming and mind-mapping as pre-writing exercises but for ESL/EFL learners this is easier said than done. The student is most probably thinking in his native language while brainstorming or mind-mapping, and then to convert this to English might not be the easiest thing for a student operating at the elementary or pre-intermediate level. The Questions technique on the other hand provides a convenient easy "lead in" to the whole enterprise of paragraph writing. Since the questions are already framed and ready, one already has a place to start. Just begin answering the questions, there's no need for head scratching on where to begin!

"Writing is such an important learning tool because it helps students to understand ideas and concepts better' (Voon, 2007). It is not enough, simply, to view language skills to be able to write accurately and fluently. What instructors do in EFL teaching is to 'slow down language processes, analyse what is (or should be) happening and articulate what first-language users take for granted' (Moody, 2005). Therefore, students, who are still learning the process of thinking through writing, require their teachers' help to structure and organize their ideas. This is what the Questions technique tries to do.

The Questions technique is for the very weak beginner but it is also meant for ESL/EFL learners operating at other levels. The Questions technique can be likened to the two support wheels attached to the bicycle of a 3 - or 4 year old child. As the child uses this support system for a while he/she gains confidence and skills and then can ride the bicycle on his /her own. The same applies to paragraph writing. After being exposed to the Questions method for some time students will gain confidence in providing written responses to a pre-arranged set of questions. And as they develop paragraphs in this manner over a longer period of time, it is almost certain they will learn to write their own paragraphs without using questions, or at least using them in more advanced, novel ways. Besides being relevant to different ability levels, the Questions technique can be applied to various kinds of paragraphs, be they narrative, descriptive, expository, argumentative, etc.

Having a positive attitude to English in general and writing in particular cannot be overstressed (Ahmed, 2015; Al Asmari, 2013; Al Noursi, 2013; Al Samadani \& Ibnian, 2015; Alkaff, 2013; Khan, 2016; Tanni, 2015). As the Questions method becomes familiar to students, their comfortability with the technique increases. And as they find more ease in writing using this approach their attitude to writing might change. This could result in a change to a more general positive attitude towards the English language.

\section{References}

Abbott, R., Berninger, V., \& Fayol, M. (2010). Longitudinal relationships of levels of language in writing and between writing and reading in grades 1 to 7. Journal of Educational Psychology, 102, 281-298.

Ahmed, S. (2015). Moroccan female rural students' attitudes towards learning English. Arab World English Journal, 6(4), 291-305.

Al-Khasawneh, F. M. S. (2010). Writing for academic purposes: Problems faced by Arab postgraduate students of the college of business, UUM. ESP World, 9(28), 1-23.

Al Asmari, A. (2013). Saudi university undergraduates' language learning attitudes: A preparatory year perspective. International Journal of Asian Social Science, 3(1 1), 2288-2306.

Al Noursi, O. (2013). Attitude towards learning English: The case of the UAE technological high school. Educational Research, 4(1), 21-30. 
Al Samadani, H., \& Ibnian, S. (2015). The relationship between Saudi EFL students' attitudes towards learning English and their academic achievement. International Journal of Education and Social Science, 2(1), 92-102.

Alkaff, A. (2013). Students' attitudes and perceptions towards learning English. Arab World English Journal, 4(2), 106-121.

Aryadoust, V. (2014). Examining the development of paragraph writing ability of tertiary ESL students: A continuous assessment study. Asian Journal of the Scholarship of Teaching and Learning, 4(3), 153-179.

Atkinson, D. (2003). L2 writing in the post process era: Introduction. Journal of Second Language Writing, 12(1), 3-15.

Benevento, C., \& Storch, N. (2011). Investigating writing development in secondary school learners of French. Assessing Writing, 16(2), 97-110.

Berninger, V. W., Abbott, R. D., Swanson, H. L., Lovitt, D., Trivedi, P., Lin, S. J. C., \& Amtmann, D. (2010). Relationship of word - and sentence - level working memory to reading and writing in second, fourth, and sixth grade. Language, Speech and Hearing Services in Schools, 41, 179-193.

Ghabool, N., Mariadass, M. E., \& Kashef, S. H. (2012). Investigationg Malaysian ESL students' writing problems on conventions, punctuation, and language use at secondary school level. Journal of Studies in Education, 2(3), 131143.

Khan, I. (2016). Positive attitude and English language learning: Psycho-pedagogic connections. Arab World English Journal, 7(1), 432-444.

Maros, M., Hua, T. K., \& Salehuddin, K. (2007). Interference in learning English: Grammatical errors in English essay writing among rural Malay secondary school students in Malaysia. e-BANGI. Journal of Social Sciences and Humanity, 2(2), 1-15.

Milner, J. O., Milner, L. M., \& Mitchell, J. F. (2012). Bridging English (5th ed.). Boston: Pearson.

Moody, J. (2005). Pragmatics and reading: Towards a teaching methodology. Paper presented at the Paper Presented at the 11 Annual TESOL ARABIA International Conference.

Musa, N. C., Lie, K. Y., \& Azman, H. (2012). Exploring English language learning and teaching in Malaysia. GEMA Online Journal of Language Studies, 12(1), 35-51.

Myles, J. (2002). Second language writing and research: The writing process and error analysis in student texts. TESL$E J, 6(2), 1-20$.

Nation, I. S. P. (2006). How large a vocabulary is needed for reading and listening? The Canadian Modern Language Revierw, $63(1), 59-82$

Nunan, D. (2003). Research methods in language learning. Cambridge: Cambridge Univ Press.

Nunan, D. (2015). Teaching English to speakers of other languages: An introduction. New York: Routledge.

Saeidi, M., \& Sahebkheir, F. (2011). The effect of model essays on accuracy and complexity of EFL learners' writing performance. Middle East Journal of Scientific Research, 10(1), 130-137.

Sokolik, M. (2003). Writing. In D. Nunan (ed.) Practical English Language Teaching. New York: McGraw-Hill.

Tanni, Z. A. I. (2015). Attitudes towards English among AL-Quds open university students in Tulkarm branch. World Journal of Education, 5(3), 139-147.

Voon, F. C. T. (2007). The Effects of the process-genre approach to writing instruction on the expository essays of ESL students in a Malaysian secondary school. Unpublished PhD Thesis, Universiti Sains Malaysia, Penang, Malaysia. 
Addendums 1 and 2: Sample of checked script from Control and Experimental Groups

Addendum-1. (Control Group).

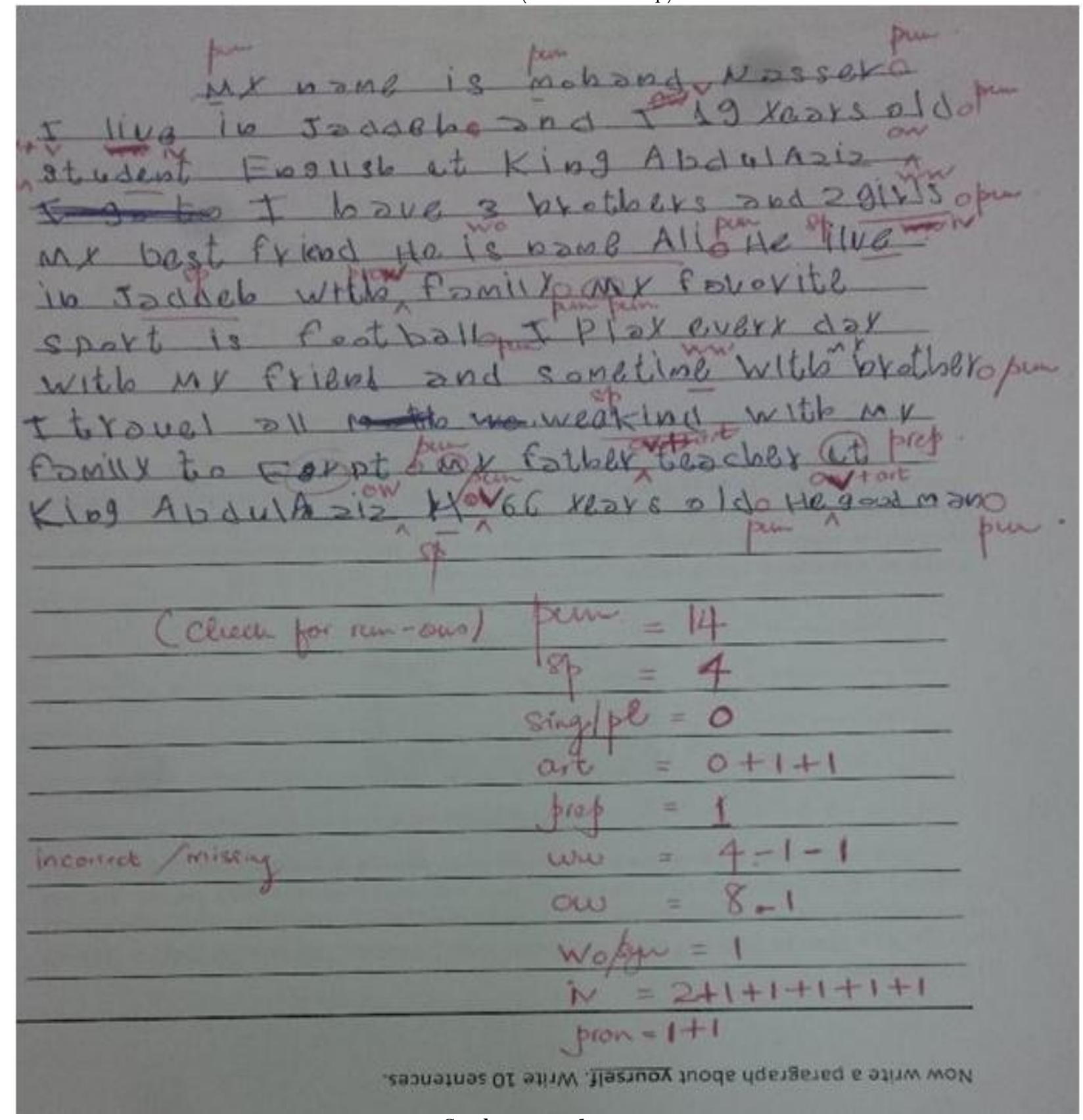

Student sample 1 
Addendum-2. (Experimental Group).

\section{Exercise 2}

Rewrite only the answers to the following questions. PLEASE WRITE AS A PARAGRAPH.

What is your name? In which district do you live? When did you first move to this district? Do you live in a house or apartment? How many bedrooms are there? What can you see from your bedroom window? is your neighborhood busy or quiet? Which shops are near your house? Which shops are far from your house? What is the biggest problem in your neighborhood? Do you like your neighborhood?

My name is oth man AL-1 smarl. Ilive inalrawabidistrict. 1 moved to this districh in 1977 . Ilive in a house. There are 4 bedrooms. Ican seepanda fromm y bedroom windowe. My neighbothood is bilsy. No shops nearin my hause. The miga mall far from mg hause. The biggest problem in my neighborhood is dirt? yes. Ilike my neighborhood.

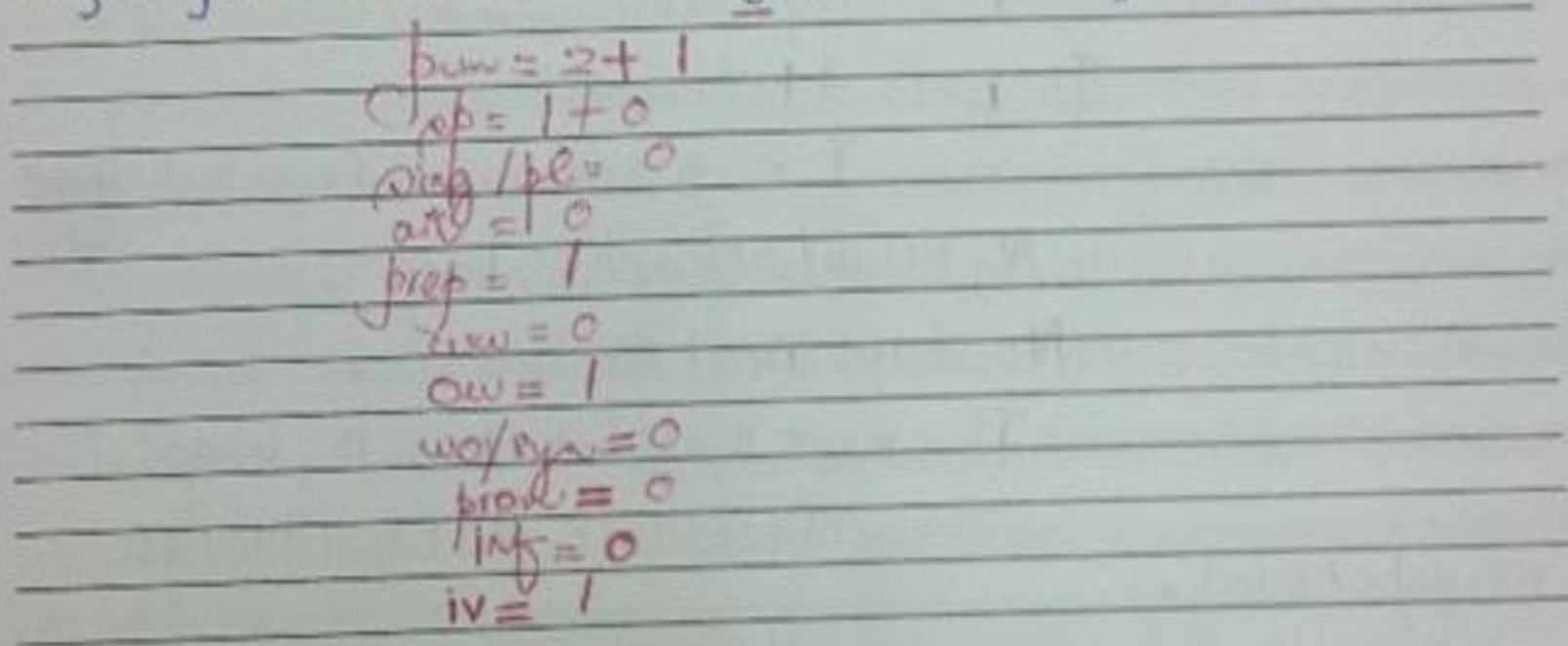

